\title{
Colorism, Mimicry, and Beauty Construction in Modern India
}

\author{
Baiq Wardhani, Era Largis, Vinsensio Dugis \\ Department of International Relations, Faculty of Social and Political Sciences \\ Airlangga University \\ Jl. Dharmawangsa Dalam, Surabaya 60286, Indonesia \\ baiq.wardhani@fisip.unair.ac.id \\ Date Submitted: 1 August 2018; Accepted: 10 September 2018
}

\begin{abstract}
Abstrak
Colorism adalah bentuk politik warna kulit. Mempertahankan warna berarti melestarikan politik diskriminasi. Di negara pasca-kolonial India, warna kulit menjadi simbol kekayaan dan kelas sosial. Praktik ini terkait dengan globalisasi dan kapitalisme, dan dilestarikan di dalam struktur sosial. Tulisan ini menjelaskan praktik diskriminasi dan penindasan pada wanita poskolonial India yang berdampak pada perubahan cara berpikir dan identifikasi diri terkait dengan warna kulit. Penulis berpendapat bahwa banyak wanita di negara poskolonial berasumsi bahwa warna kulit menentukan status sosial dengan menginternalisasi keyakinan bahwa orang kulit putih lebih disukai secara sosial. Sejalan dengan asumsi dalam studi poskolonial yang menempatkan masyarakat adat sebagai subyek perifer. Persoalan kompleks yang diciptakan selama era kolonial pada dasarnya tidak lenyap di era poskolonial. Salah satu konsekuensi dari mengubah identifikasi diri adalah munculnya pewarnaan kulit dalam bentuk pemutihan kulit, yang kemudian menjadi fenomena umum yang berkembang di negara-negara berpenduduk kulit berwarna yang memiliki sejarah kolonialisme Barat. Penggunaan pemutih kulit yang meluas oleh perempuan dan laki-laki di negara-negara berkulit berwarna adalah keberhasilan kapitalisme dalam mengeksploitasi kepercayaan diri yang rendah di antara orang-orang dari negara-negara kulit berwarna. Standar kecantikan Barat adalah bentuk kekerasan struktural dengan cara menghilangkan karakteristik budaya unik dengan mengubah gagasan bahwa putih adalah warna yang ideal.
\end{abstract}

Kata kunci: colourism, poskolonialisme, standardisasi kecantikan

\section{Abstract}

Colorism is a politics of skin color. Maintaining color is preserving the politics of discrimination. However, in the post-colonial country of India, skin color is a symbol of wealth and social class. This practice is related to globalization and capitalism, and is preserved in social structures. This paper explains the practices of discrimination and oppression in Indian postcolonial women that have an impact on changing ways of thinking and self-identification related to skin color. We argue that many women in the postcolonial state adopt assumption that skin color determines social status by internalizing the belief that whites are socially preferred that justifies a key element in the post-colonial study on the observation of the process by which indigenous peoples are placed as peripheral subjects. The complex inferiority created during the colonial era basically does not disappear in the postcolonial era. One consequence of changing selfidentification is the emergence of colorism in the form of skin bleaching, which then becomes a common phenomenon that develops in colored populated countries that have Western history. The widespread use of whitening skins by female and male in non-white skinned countries is the success of capitalism in exploiting poor self-confidence among the people of the colored nations. Western beauty standards are a form of structural violence since they have removed the unique cultural characteristics by changing the idea that white is the ideal color.

Keywords: colorism, post-colonialism, beauty standardization

\section{INTRODUCTION}

Having a fairer tone of skin is an obsession of many women in India. This explains a high rate sale of whitening products in India. Srivastav (2017) claims, skin whitening market in India values at over $\$ 200 \mathrm{~m}$. Among them is Fair and Lovely that currently holds a $50-70 \%$ share. India is one of the largest markets for skin whitening/lightening products in the world with an estimated $60-65 \%$ of its female population using skin whitening/lightening products, with the largest consumers of $16-35$ years old 
(Franklin, 2012, p. 9). Every year Indian community consumed more than 250 tons of whitening cream, and in 2010, according to AC Nielsen, whitening cream sales reached US $\$ 432$ million, and in 2012 it became US\$634 million (Pradityo, 2014, p. 114). Since 2000 there have been over 30 skin whitening/lightening products in India, and even sales are higher than Coca-Cola soda products (Franklin, 2012, p. 36). Bleaching or skin lightening products in India fall into the category of FMCG (Fast Moving Consumer Goods) in Personal Care Products. Based on data from the Market Survey in India on the sector, whitening or lightening products have a substantial portion of $56 \%$ or Rs 11.75 billion from the total skincare sector worth Rs21 billion (Italian Trade Commission, 2008, p. 17). In India, selfconfidence is a big issue, particularly among the darkskinned female, and is exacerbated by a caste system. Having a whiter or brighter skin is related to form of perception on the hierarchy of skin tones that are closely related to the history of colonization. The increasing use of skin whitening products in the world is shown by the increasing number of types and sale of these products. Rondilla (2012, p. 3) describes, in 2005 , there were 62 new skin whitening products issued in the Asia Pacific market, which until 2009 increased to an average of 56 other new products. Suvattanadilok (2013, p. 1) says that based on the Global Industry Analysis, the sale of whitening or skin lightening products increased over time in the global cosmetics market. In 2012, this product increased by 2 billion sales in the Asia-Pacific market. This sale or promotion of whites has been marketed in Asia for the last 10-20 years with Market Share on the product increasing in particular products from Japan and China over the previous 5-10 year (Mire, 2012, p. 274). Discussing the connection between postcolonialism and the use of skin whitening/lightening products to change skin tone is an important subject. According to Jemima Pierre (2008, p. 11), skin bleaching or any act of whitening should be included in the discussion of global structures due to differences and powers or as a form of racial hierarchy of the world. The ideology of whiteness as a form of power influences socio-political conditions, and even it impacts to their daily lives. As a globalizing phenomenon, whitening or brightening skin tones suggests that there is an issue of color discrimination that is closely related to colonialism, slavery or oppression in the past (Robinson, 2011, p. 86).

\section{THEORETICAL FRAMEWORK}

\section{COLORISM IN POSTCOLONIAL PERSPECTIVE}

Homi Bhabha is well-known for his analysis of distortions over the original subject. His thoughts about mimicry and hybridism, radically question about the effectiveness of colonialism. In Of Mimicry and Man: The Ambivalence of Colonial Discourse (1984) Bhabha discusses the mimicry, which is the behavior of imitating whites by natives. Mimicry, thus, is an ambivalent strategy whereby subaltern people simultaneously express their submissive attitude to a stronger party and subvert that power by imitation. The concept of mimicry explains how colonial rulers encouraged colonized subjects to 'imitate' the invaders, by adopting custom culture, assumptions, colonizing institutions and their values. What happens is, mimicry has never been a simple reproduction of the properties desired by colonizers. Instead, the result is a 'fuzzy copy' of the invaders, because mimicry is another form of mockery. According to Bhabha (1994, p. 86), imitating colonial culture, behavior, manners, and colonial values contains elements of mockery as well as certain 'threats'. Thus, mimicry expresses limitations in the authority of colonial discourse. According to Bhabha (1984, p. 126),

"...colonial mimicry is the desire for a reformed, recognizable Other, as a subject of a difference that is almost the same, but not quite. Mimicry is, thus, the sign of a double articulation; a complex strategy of reform, regulation, and discipline, which 'appropriates' the Other as it visualizes power." 
Furthermore, Fanon in Black Skin, White Masks (1952) argues, colonization does not only occur in terms of spatiality and economic benefits, but also leaves a profound psychological impact in the relations of colonized and colonialists. Through Western cultural insemination, Fanon saw that colored peoples perceive their culture, ideology and practice of their daily life as being inferior to whites. Fanon claims that the colored people reject their own social and cultural identity as they were inferior to the whites, thus creating a sense of envy to the colonizers. Colored people began to adopt the same values and ideals as the invaders. The long-term impact is that, the colonized peoples create a vision that deviates from their own world because they understand they will never and cannot become a white nation. Such thinking systems have created a continuous and prolonged power imbalance that results in a complex inferiority among the people of the colonized peoples. The colonial power has radically succeeded in influencing the way people see themselves in relation to 'others' who have different skin colors, religions and ideologies. Fanon in The Wretched of the Earth (1961) explains, the colonizers successfully make the colonized feel inferior. As a result, the colonized feel they need to wear a white mask (i.e. culture) as the only way to overcome that psychological disability, as such, European culture is ideal for imitation by natives. They use violence and upheld divide and rule strategies to keep the indigenous people down.

Fanon's criticism centers on his view that imperialist powers not only colonize the lands and territories of colored nations, but also colonize their view of the world, termed 'epistemological colonialism'. One of the colonization effects of knowledge presented by Fanon is the 'alienation of black man'. Alienation refers to the classification of colonizers to the colored peoples who have lower intellectual abilities. Racism is a system maintained by the West to demonstrate the ability of the West to subjugate non-Westerners who can easily be exploited by the West. When the postcolonial period came, colonized countries seemed to have been freed from Western oppression and they were given the freedom to govern themselves. But in fact, Western imperialism against the developing world continues, one of them through the neo-liberal practices instilled by transnational corporations that exploit the cheap labor market in postcolonial countries. The inferiority complex implanted during colonization has a devastating effect on the minds of colonized people by altering their ontological perspective on the understanding of superior-inferior relationships with other 'groups' (Fanon, 1968). In the same vein, Edward Said's theory of postcolonialism is based primarily on what he considers to be a misrepresentation of the Orient as Western explorers do through their poetry, novel, and theorized works by the philosophers, political and economic scientists as well as administrators of the empire since Napoleon's occupation in 1798. According to Said, these Westerners have always shown the image that Orients are primitive and uncivilized, regarded as a comparison in contrast to the progress and values of Western civilization. In a very influential work, Orientalism (1978), Said considers that Orientalism is a style of thought based on the ontological and epistemological distinctions made between Orient and Occident (West) (Hamadi, 2014)

Hence, postcolonial studies are at the intersection of the debate between race, colonialism, gender, politics and language (Ashcroft, Griffith, and Tiffin, 1988). It is a paradox that in the midst of the desire to self-determination and the struggle against colonialism, there is the spread of values, norms and patterns of thinking and behaving like the rulers. Once there is physical and armed resistance to the goals of colonialism, there is at the same time acceptance of some cultural elements brought by the colonial authorities. Civilian missions propagated by the colonial authorities are consciously adopted by local communities with long-term consequences. Indigenous peoples are uncomfortable with the customs and structures of local systems that they have 
undergone for generations and there is a strong desire to change the system with the new system brought by the foreign ruler. Colonial thinking begins when there is an assumption that the writings, art, legal system, science and practice of social culture are always racialised and unequal, in which the colonial rulers position themselves as representative parties and indigenous peoples as represented. Post-colonialism divides historical, political, cultural areas into 'western' and 'eastern', implies not only a physical demarcation, more importantly, the division has created binary opposition. Postcolonialist writers like Ashcroft, Griffiths and Tiffin (1988) argue that postcolonialism refers to the cultural enslavement occurred during colonialism to the present days.

\section{ANALYSIS HOMOGENISATION AND BEAUTY STANDARDISATION}

Many women from postcolonial countries think that skin color determines social status. Local beauty standards no longer apply because women have been deceived by the beauty standards set by colonialist agents. They internalize the belief that whites are the socially preferred. This assumption is misguided, but it has already been believed to be true. This assumption arises as a result of the mimicry behavior gradually but realistically internalized by the colonialists to the colonized peoples. Mimicry behavior has generated a variety of harmful negative excesses. In a more general discussion, mimicry behavior is not limited to skin color but physical appearance, such as face shape, posture, height, dress behavior, and all aspects of lifestyle in developing country societies. It is a fact that past and present-day western interactions have changed people's behavior in developing countries by instilling trust based on internalization by the western side that 'the west is beautiful', 'white is beautiful', resulting in a process Westernization of beauty. The beauty standards that refer to, and imitating, the western style of beauty that occurs among the people of the developing world bring more negative consequences.

The homogenization of beauty began in 1914 following the growth of multinational companies Siemens and Singer who produce sewing machines. The beauty trend does not only about the beauty of fashion but also the cosmetics company that also opens branches abroad featuring figures of the cosmetics industry of the United States such as Elizabeth Arden, Max Factor and Helena Rubeinstein; The body perfume products manufactured by France, Britain and Germany, such as Piever, Gurlian, Rimmel, and Muehlens, as well as bath soap products issued by US companies such as Lever Brothers and Procter \& Gamble (Jones, 2011, p. 890) support the growth of western-style beauty standard. The homogenization of beauty begins with the assumption of ideal beauty as propagated by the multinational corporations of the colonial countries. A paper cited by Jones (2011, p. 891) asserts that the West began to spread ambition to standardize beauty by stating, "as Western culture and influence expanded during the nineteenth century, Europeans and Americans became increasingly curious about, if not respectful of, the rest of the world, writing in scientific journals about the apparent differences in beauty ideals." Furthermore Jones (2011, p. 891) suggest, “... The international growth of the beauty industry ... drove a worldwide homogenization of beauty ideals. Beauty ideals, assumptions and routines prevalent in the West spread as global benchmarks. Beauty also came to mean white." In accordance with previous writers, Burke (1996, pp. 17-34 in Jones 2011, p. 892) inserts, colored racial stereotypes are of potential advertisement of bath soaps and cleaning products that are an important aspect contributing to Western civilization missions to non-Western societies. The history of beauty products and body cleanser explains that the West has set the standard of beauty and homogenization since the colonial period.

Skin color is one of the characteristics that distinguish the origin of a group of civilizations. 
Different skin colors do appear to be just physical markers, but in reality skin color plays an important role as social capital. Preference to a particular skin color is not just a myth that develops in society but it factually affects how society behaves. Colorism has become a global issue especially with the advent of globalization and technological advancement. Globalization has facilitated the ongoing colorism by exporting Western culture, products, and imperialism, including skin color preferences (Hunter, 2007). The global media has caused Eurocentric physical characteristics to be more interesting than the physical features of other races: lighter skin tones are preferred over dark colors. There is a tendency that countries in the intersection of the internalized values of colonialism have a greater tendency to value higher light colors. Bright skin is an indicator of acceptance of beauty standards in global markets. The spread of colorism became very widespread and intensive with the help of mass media featuring the figure of world celebrities who represent Western culture. The spread of this thinking construction means that having bright skin not only provides access to a better life but also a cultural obligation to follow. It is not surprising that colorism is very difficult to fight.

The ideology of colorism is sustained systematically through the dissemination of the image in the mass media which gives rise to a new definition of beauty. In this way beauty manifestations become homogeneous and standards follows the willingness of the spreading party. Western beauty features that show the figure of tall and slim body, blond hair, blue eyes and white skin to the standard accepted in developing countries. The massive Hollywoodproduced film industry that continues to feature Caucasian racial stars helps expand the image of the standard of beauty the West wants. Changes in beauty standards cannot be separated from the legacy of colonialism with white supremacy. In the postcolonial period, the supremacy of white supremacy was done more massively in various ways, both in print and electronic media. The ways in which this has successfully led women to abandon traditional cultural ideas that have been culturally believed and replace them with Western-standardized beauty. The manifestation of westernization of beauty is shown by altering physical appearance by altering the color of the skin and the shape of the face and body causing the high sales of skin whitening products and plastic surgery practices.

Based on Bhabha's theory of mimicry, the obsession to imitate white people has been transformed into the skin-bleaching behavior of many colored peoples. Mimicry behavior becomes a strong reason for the growth of skin lightening products industry in many developing countries in Asia, Africa and the Caribbean. Community demands on skin lightening products are labeled as 'beauty products' (with various designations such as skin lighteners, skin whiteners, skin-toning creams, skin fading gels) are very high. Consumers in some countries even use harmful skin products that can be purchased freely because they are made without adequate supervision, which can actually affect skin damage. Consumers of the postcolonial state do this merely to be acknowledged parallel to the race-white race that they believe has a higher value. Eurocentric appearances seem to be a necessity and standard.

Based on this fact, globalization becomes a new driving force for the proliferation of mimicry behavior. The meaning of beauty undergoes a homogenization process. Previously, beauty standards varied from one region to another. Traditional thinking about the feminine beauty varies across cultures and generations: the beauty of Latin American women is measured by the body, Asian women with oval faces and black hair, Africa with exotic skin color. This view has passed with the advent of globalization that changed traditional thinking about beauty. Globalization makes people develop norms driven by multinationals that introduce their product brands through advertising. Advertisements seek to build an emotional bond with the audience by displaying a variety of interesting images. As 
globalization increases interaction and integration among people around the world, the meaning of beauty also shifts (Globalization 101, 2008). The spreading of beauty definition was done systematically and supported by various parties such as visible in the world-class beauty contest that provides an international standard on beauty. World beauty contests base the assessment criteria on the face, height, size and posture proportion. Contest organizing is done in collaboration with US cosmetics companies. The winners became ambassadors for the advertising of her beauty products (Globalization 101, 2008).

Among the Eastern peoples, India and China have a fairly high middle class population. Beauty products are widely available, purchased by men and women with the goal of brightening their skin in hopes of achieving a better life, higher paying jobs, and higher class couples. The practice of skin whitening has perpetuated colorism, which is a preference for, and privileges skin light rather than dark skin. Colorism is manifested in various forms in different parts of the world, and is present in various societies that have experienced colonialism with the supremacy of white ideology. Modernity and capitalism give women more choice to make themselves more easily in improving their social status. These symptoms indicate that the sale of skin lightening products is cultural imperialism and the remnants of colonial inheritance, which is demonstrated by the belief of many women that being white is true, even as a benchmark for perpetuating identity by altering local cultural norms about the meaning of beauty.

Gelles' (2011) research about the meaning of beauty in India shows that there has been a major change in the definition of beauty. In pre-colonial times beautiful Indian women are seen with local indicators, such as moon-like faces, black hair, wide hips, round breasts, small belly, and arched eyebrows. Once there are differences in tastes from time to time but the indicator of beauty is measured according to local tastes in those days. Skin color is certainly not a new issue for Indian women. Indian society has quite a contrasting color difference between those living in the north and south. For most people, naturally lighter skin tones are more desirable. Bright color becomes a common preference that develops in India that is increasingly rising due to bright skin as if it were a guarantee for social acceptance and welfare improvement. But so far there have been no attempts to fabricate skin color, especially in dark-skinned Indian women. The strong desire of Indian women to be lighter and even white skin marks the narrowing and reduction of the meaning of beauty. One of the important moments that legitimized the narrow meaning of beauty was the appearance of beauty products under the Fair and Lovely brand in 1975 which was later followed by other brands such as Carefair (Gelles, 2011, p. 13). Beauty salons are filled with customers who want to change skin color with skin whitening products that are advertised on television. Uniformity of beauty definition develops, not only applies to skin color but also hair color, body shape and style of dress. The concept of body image, thus, is a dynamic concept following the times. New standards about body image became new issues among Indian society about beauty disseminated by the appearance of beautiful actresses on television. Demands for changes in body image increased sharply with more and more Bollywood producing film. According to mental health expert Fatima Chowdury (in Gelles, 2011, p. 26), “... like beauty, fairness and perfect body size are glamorized and are associated with a lot of approval and acceptance... reinforced in the minds of young women who then start to set unrealistic standards for themselves, [and] consequently employ unhealthy ways to achieve them."

Instead of being a healthy lifestyle, changing body image has become a national health issue in India. The posture of the average Indian is seen as a posture that is not ideal by Western standards; hence it is necessary to make efforts to get closer to the ideal 
shape desired. The number of cases of dietary aberrations such as anorexia nervosa and bulimia among young women is an integral part of the westernization of beauty. In the social order, people who think that having black skin and poor physical posture is a threat because it reclaims to discriminatory social segregation and marginalize dark skinned people. Indian society, especially dark-skinned, has a complex of identities rooted in the coming history of the Aryans who claim themselves superior because of their whiter skin color. Colorism in India is thus an attempt to escape the oppression of the white people, in this case the Aryans and the West. White skin is synonymous with aristocracy. This obsession is more pronounced among the lower races of dark-skinned Indian women. Once there has been an attempt to create the natural color of Asia, Western standards of beauty are still ideal and normal values, so those who are not in the standard are doing "ethnic repairs" by undergoing a series of actions like plastic surgery. Western-centrism and western cultural hegemony propagated through various media causing colored peoples to have psychological syndrome about the need for standardization and homogenization of beauty.

\section{COLORISM AND CIVILIZING MISSION}

Some previous research on skin bleaching has been done by many scientists, especially those happened in African countries such as South Africa, Ghana, Kenya, Tanzania, Senegal, Mali, Nigeria, Jamaica and Asian countries such as India, Japan, Indonesia, Thailand, the Philippines, South Korea as well as Latin American countries such as Brazil. The results of the study agree that there is a close relationship between skin bleaching and colonial history (Blay and Charles, 2011, p. 1). In India, however, caste is a system that posits individual existence in society not as a single individual but as a functional part in an interdependent system, thus relying on their primary task in each of the varna they are born into. It is not only as a form of division of labor but also a form of social division that determines comprehensively how they should live their social life (Suradkar, 2011, p. 44). According to Deshpande (2010, p. 20), the fourth division of the caste is based on the need for the four functions of each caste in the society which are the four main objectives of man and society, religious and educational functions, military and political, economic, and blue-collar workers which are then used as the basis of the classification of roles and social status for Indian society to live more regularly. Civilizing mission began on the arrival of British colonialism by spreading the values, ideas, culture they brought as superior. This is closely related to Darwin's theory of survival of the fittest in which British colonial society believes that white Europeans are the most fit creatures after natural selection in the world and they have an obligation to spread their ideas, values, culture to those who backward or inferior (Classzone, 2002, p. 482). This is supported also by Rudyard Kipling (1899 in Classzone 2002, p. 482) in his article The Whites Man's Burden as a form of European colonial view of another inferior society.

In relation to that, Frantz Fanon (1965 in David, 2014, p. 6) asserts, there are four phases of colonialization in the colonial model in understanding colonialism and internalization of colonization in colonial society. The first phase is the forcible entry of foreign groups into an area to exploit natural resources, including the surrounding population through slavery and cheap labor. The second phase is when the colonial rulers apply their culture, and dissociate the indigenous culture with the colonial culture. This transformation of indigenous culture distinguishes between colonial culture whose way of life is considered more civilized (civilized) with the culture of the people who become more inferior and less savaged colonies (David, 2014, p. 7). When society has clearly known the differences between colonial and colonies, the third phase begins to take place where colonized peoples are depicted as wild, uncivilized, and cruel, so the colonists or colonials have an obligation to control, tame and civilize them. 
This phase shows the existence of tyranny, domination, oppression required to carry out these civilization missions. The fourth phase occurs when the creation of a society in which its economic, social and economic institutions are designed to benefit and retain the superiority of the colonial and sustainably conquer the colonized society (David, 2014, p. 8). This fourth phase can be seen from institutions such as churches, schools in their colonies, where parties assimilated or agreed with colony style will be rewarded while punishing those who do not follow or oppose (David, 2014, p. 8).

One of the importances of the second phase is marked by the weakening of the caste system when the British colonials began to reign in India with new knowledge systems and civilizing missions. Antonio Gramsci (in Suradkar, 2011, p. 45) says that there is a relationship between class domination and hegemony, which always uses state power to dominate and use ideological and cultural hegemony to make the subaltern agree on that dominance. The British colonial rule in India used both domination and hegemony methods in the second phase of colonization. The British colonials managed to change the conditions of the structure of society into the structures they shaped and dissociate indigenous cultures, to show that colonial culture was more civilized than the Indian people's culture which was considered savage.

The emergence of middle class society in India during the colonial period then raised the question of indigenous Indian culture or custom which is considered savage (Gull, 2014, p. 121). It can be analyzed through Orientalist thesis where the world becomes Western and Orientals, where in the feminist perspective, Oriental women are passive, unable to express their voice (Hasan, 2009, p. 30). Western women are the opposite of non-western women or orientals women who are considered ignorant, submissive to patriarchal dominance, poor, uneducated, tradition-bound, domestic, familyoriented, and victimized. Meanwhile, western women are women who are educated, modern and have control over their body and sexuality and have the freedom to make and deliver their choices and participate in civilization missions through their feminist agendas that are inconsistent with Oriental women (Hasan, 2009, p. 30). It explains how clashes and ultimately led to the disappearance of indigenous cultures of Indian people through the values and movements that arise in terms of women's issues. Feminist Antoinette Burton (in Chitnis and Wright 2007, p. 1324) clarifies that the role of British colonial women in strengthening the mission of civilization is to teach, inform, show how Indian women can earn their rights as idealized Victorian Women who are regarded as the superior female standard at the time and is a form of white feminist burden (Chitnis and Wright, 2007, p. 1325).

Indian women are seen as subalterns that are not allowed to speak, construct identity and what happens in their lives. Thus, when the British colonials entered India, there was a clash between the indigenous cultures of Indian society that were later faded and replaced by the values brought by the British colonials. The history and focus of postcolonial feminist theory is the existence of their condition as women in the former colony country, especially in terms of their identity and role (Ascorf, Tiffin and Griffiths, 1995, p. 250). The process of colonization by Ann Stoler (2011 in Saraswati, 2011, p. 117) is a process of demasculinization against male colonized peoples, but instead, raises hypermasculinity against colonial men. This is related to the existence of white supremacy, in which the white male colonial is the most masculine and superior compared with the men of the colonized country. Anne McClintock (1995, p. 120) adds that colonized and territorial communities are feminized through conquest by masculine colonial powers. Territory is one of the symbols of property in colonial patriarchy that must be mastered and owned, so that the occupied men will lose the symbol of its masculinity. 


\section{THE POSITION OF INDIAN WOMEN}

The introduction of British colonialism changed the social stratification system in India, where the caste system became more open and those impacts to the abolition of women's oppression from earlier traditional periods. However, the emergence of movements and issues about women at that time was closely related to the wishes and agendas of Indian patriarchal society to achieve the reform of independence and nationalism. The highest social position in this period is held by British colonials as the most superior. The value then affects the position and role of Indian women at the bottom because of 'double oppressions', since the level of superiority and masculinity embraces the British colonial system, including women at the time. Double oppression is the form of internalization of colonial oppression that influenced the behavior and way of thinking of Indian women. Oppression perpetrated against the colonized society usually results in self-doubt, confusion of identity, and inferior feelings (David, 2014, p. 10). This creates a further form of double oppression: Indian women are continuing to remain in their local patriarchal oppression (for being a women), and under the oppression of the legacy of white legacy standards (for being a non-white).

The patriarchal system of Indian postcolonial society about the demasculinization of Indian men in the colonial period has changed when the British left India. Indian men get their chance back to claim their masculinity, create their own manhood and emerge as a new master in postcolonial society. Women remain the object of property both in the context of the colonial and post-colonial period. As a part of the internalized oppression in India's postcolonial society, they put the high-value of the standard of women's, thus, are the legacy standard of British colonialism, namely Victorian or white beauty ideal (Saraswati, 2011, p. 120). The 'white ideal of beauty' is defined as the idea or standard about universal beauty using white standards brought by European colonies and tend to Eurocentris (Rondilla, 2012, p. 12). This concept is closely related to the existence of White Supremacy brought by the European colonial in which one manifested in the concept of the 'white ideal of beauty,' which is a standard form constructed to measure and ensure the superiority of white colonial skin. Hunter (2011, p. 12) adds, the 'white ideal of beauty' contains aspects of the European colonial culture, ideas and lifestyle that associate whiteness, as a form of modernity, sophistication, beauty, power, and wealth. The idea of white beauty is continuously asserted into non-white society through colonial values and civilization. It justifies the existence of white supremacy that uses it to distinguish between civilized or savage. Discrimination occurs because beauty indicators use colonial patriarchal standards. The most beautiful women are white women, while indigenous or non-white Indian indigenous racial women are out of the ordinary. This concept is considered unrealistic and detrimental to women in the postcolonial state because naturally Indian women unattainable to reach that standard. This led to a psychological effect on Indian women who responded to the internalization of the standard by bleaching the skin. This resulted in the appreciation of white ownership as a form of assets or social capital among Indian postcolonial women. Having white skin is a symbol of privilege in social life and hope for a better life.

The Postcolonial approach believes, long-term oppression experiences can lead individuals to internalize the inferiority they gain from colonization through processes and impacts left behind by colonization or due to decolonization in social, cultural, economic and political terms. Oppression occurs when a group has access to power and privilege than any other group. These powers and privileges are used to maintain the status quo or the dominance of the group. The oppression that took place in India was evident from how the patriarchal system of caste, colonial and postcolonial history brought about a form of injustice to Indian women. Oppression results in the emergence of differentiation or binary 
opposition in society, enters into certain groups (dominant / dominated, powerful / powerless, superior / inferior, oppressor / oppressed). The group's membership determines the level of power, opportunity and ability of an individual to access resources (David, 2014, p. 3). The oppressor or those who have dominance over power use their access to resources and privileges to impose their will and perspective to the oppressed party.

Duran and Duran (1995 in David, 2014, p. 9) claim, internalized oppression works within the scope of individuals and groups to maintain a favorable power structure for the oppressed. In line with the thesis, Neville, Coleman, Falconer and Holmers (2005 in David, 2014, p. 9) find a negative relationship between internalized oppression and the individual level in validating the existence of racism / colorism, where the more oppressed an individual, the more he / she deny the reality as the oppressed party. Internalized oppression can also lead to segregation in groups, even discriminating against other members and choosing to emulate or identify itself like its oppressors. They do so in an attempt to be the same, and identify themselves, like members of their oppressive group. The party seeks to erase the value or devalue its group members by rejecting its culture. Hall (2006, p. 13) says that colonization and oppression both historically and contemporary make it inconceivable to believe that light or white skin is more profitable, attractive, and desired. Internalizing the idea of skin color results in the desire to have as vivid or as bright a color as possible for social mobility and acceptance. The desire is manifested in the use of whitening cream or whitening activity at the expense of its ancestral heritage. Finally, suppression of the British colonial system also led to the concept of 'postcolonial body' as a symbol of the differences between the former colonies and colonial. The bodies or physics of colonized societies are an important feature of the system of representation, of how they interpret controls, how they are treated and the differences seen between them and their colonies (Ashcroft, Griffiths and Tiffin, 1995, p. 146). Post-colonial bodies can be recognized on visible signs of color such as skin color, hair type, and facial character, all of which become the main way to build and strengthen prejudice against a particular group. This is evident in the existence of the European colonial descent, or those who have characteristics close to the colonial people once again to reinforce the inferior and superior parties, one of which is through colorism.

\section{CONCLUSION}

The Indian postcolonial society determines that women's positions are legally and institutionally guaranteed under Indian law. But the law tends to be procedural in its feminist agenda because it is not followed by a reduction in women's oppression in the patriarchal Indian system of society. In addition, one of the legacies of British colonization that coincided with the Indian patriarchal system of double oppression still continues because of the condition of non-white Indian postcolonial women. The existence of the ideal standard of white skin becomes a patriarchal standard, which is then applied or manifested into social systems and structures in postcolonial society as something of essentially important, as asset, or social capital in the society. This is what prompted the Indian public preference of white or light, which then led to the existence of colorism and skin whitening activities. It can be concluded that with the end of British colonization, India's social stratification system became more open than ever. Social mobility makes it possible for women to change their social status through certain means such as education, work or marriage. However, the internalization of colonial oppression, primarily because of the white supremacy led to the emergence of respect for whites as part of the value embedded in the patriarchal system of Indian postcolonial society, thus causing them to have a tendency of colorism. 


\section{REFERENCES}

Books and e-books

Ashcroft, B., Griffiths, G., \& Tiffin, H. (eds.) (1995). Postcolonial Studies: the Key Concept (2nd Edition), London: Routledge.

Bhabha, Homi K. (1994). The Location of Culture. London: Routledge.

David, E.J.R. (20|4). Internalized Oppression: The Psychology of Marginal Groups. New York: Springer.

Fanon, Frantz ( 1961) The Wretched of the Earth; translated in English 1963. London: Penguin Books.

McClintock, Anne (1995). Imperial Leather: Race, Gender and Sexuality in the colonial Contest. London: Routledge.

Suradkar, Santosh Pandhari (20I I). Idea of Emancipation and Discourse on Caste in Colonial Western India (Maharashtra). Center for Historical Studies. New Delhi: Jawaharlal Nehru University.

Rondilla, Joanne L. (2012). Colonial Faces: Beauty and Skin Color Hierarchy in the Philippines and the U.S. U.C. Berkeley Ethnic Studies.

$<$ http://digitalassets.lib.berkeley.edu/etd/ucb/text/Ron dilla_berkeley_0028E_| 2807.pdf>

\section{Journals}

Bhabha, Homi (1984). Of Mimicry and Man: The Ambivalence of Colonial Discourse. Discipleship: A Special Issue on Psychoanalysis, 28 (Spring), pp. I25133.

Blay, Yaba A. \& Charles, Christopher A.D. (20I I). Skin Bleaching and Global White Supremacy. The Journal of Pan African Studies 4 (4).

$<$ https://papers.ssrn.com/sol3/papers.cfm?abstract_id $=2372 \mid 24>$

Gull, Raashida (20।4). Of Feminism, Colonialism and Nationalism in India: Drawing A Relationship. The International Journal of Social Sciences, 19 ( I).

Hall, Ronald E. (2006). The Bleaching Syndrome among People of Color: Implication of Skin Color for Human Behavior in the Social Environment. Journal of Human Behavior in the Social Environment 13 (3).

Hamadi, Luthfi (20|4). Edward Said: the Postcolonial Theory and the Literature of Decolonization. European Scientific Journal. Special edition vol.2 ISSN: 1857 788I (Print) e - ISSN I857- 743I.

$<$ https://eujournal.org/index.php/esj/article/view/368 9. Accessed |4/5/2016>

Hasan, Mahmudul (2009). The Orientalization of Gender. The American Journal of Islamic Sciences 4 (22). $<$ https://iepistemology.net/vI/attachments/89I_ajiss22-4stripped\%20-\%20Hasan\%20\%20The\%200rientalization\%20of\%20Gender.pdf> Accessed 16/7/2016.
Hunter, Margaret (2007). The Persistent Problem of Colorism: Skin Tone, Status, and Inequality. Sociology Compass. I ( I), pp. 237-254.

<https://pdfs.semanticscholar.org/b494/dfa7| | f2d486 9c7cl5a7adf9b99a0dbbccb4.pdf. > DOl: | 0. 1 | | |/j. I75 I-9020.2007.00006.x

Hunter, Margaret L. (20I I). Buying Racial Capital: Skinbleaching and Cosmetic Surgery in a Globalized World", Journal of Pan African Studies 4 (4). <http://www.jpanafrican.org/docs/vol4no4/HUNTER \%20Final.pdf. Accessed 23/5/2017>

Mire, Amina (2012). The Scientification of Skin Whitening and the Entrepreneurial University-Linked Corporate Scientific Officer. Canadian Journal Of Science, Mathematics, And Technology Education 12 (3). $<$ https://eric.ed.gov/?id=EJ984656> Accessed 23/5/2017.

Jones, Geoffrey (20 I I). Globalization and Beauty: A Historical and Firm Perspective. Euramerica. 4 I (4), pp. 885916. Institute of European and American Studies, Academia Sinica < http://euramerica.org > Accessed 09/09/2016

Pierre, Jemima (2008). I Like Your Colour!' Skin bleaching and Geographies of Race in Urban Ghana. Feminist Review 90.

<http://www.ingentaconnect.com/content/pal/0 I 417 789/2008/00000090/0000000 l/art00002> DOl: https://doi.org/l 0.1057/fr.2008.36. Accessed 09/09/2016.

Suvattanadilok, Montajula (20 |4). Skin Whitening Products Purchasing Intention Analysis. Research Journal of Business Management, 8, pp. 28-42.

<http://www.scialert.net/abstract/?doi=rjbm.2014.28 .42. DOI: | 0.3923/rjbm.20|4.28.42> Accessed $27 / 7 / 2016$

Saraswati, L. Ayu (20I I). "Why beauty matters to the postcolonial nation's masters: reading narrativesof female beauty in Pramoedya's Buru Tetralogy", Feminist Formations 3 (2).

$<$ https://muse.jhu.edu/article/448634> Accessed 22/3/2016.

\section{Websites}

Chitnis, Varsha \& Danay Wright (2007). The legacy of colonialism: law and women's right in India. University of Florida Levin College of Law.

$<$ https://scholarship.law.ufl.edu/facultypub/I74/> Accessed 23/7/2017.

Classzone, Littell. (2002). "Chapter 27: The Age of Imperialism.In: McDougal Littell Classzone (ed.), World History.

http://www.classzone.com/books/wh survey/index.cf m. Accessed 16/2/2015

Deshpande, Manali S. (2010). History of The Indian Caste System and It's Impact on India Today. Senior Project 
Paper California Polytechnic State University. < http://digitalcommons.calpoly.edu/socssp/44/> Accessed 23/7/2015.

Franklin, Imani (20I2). Living in A Barbie World: Skin Bleaching and the preference from Fair Skin In India, Nigeria, and Thailand. Center For Democracy, Development, and the Rule of Law, Standford University.

$<$ https://id.scribd.com/document/ I 68 I | 6443/BarbyWorld > Accessed 17/4/2016.

Gelles, Rebecca (20I I). Fair and Lovely: Standards of Beauty, Globalization, and the Modern Indian Woman. Independent Study Project (ISP) Collection. Paper I 45 .

< http://digitalcollections.sit.edu/isp_collection// | 45> Accessed 29/3/2017.

Hall, Alicia V. (2003). Body Image as a Function of Colorism: Testing a Theoretical Model. Graduate School Theses and Dissertations University of South Florida.

$<$ http://scholarcommons.usf.edu/cgi/viewcontent.cgi? article $=395 \mid$ \& context $=$ etd $>$.

Hall, Ronald E. (2006). The Bleaching Syndrome among People of Color. Journal of Human Behaviour in the Social Environment, 13 (3), pp. 19-31.

$<$ https://www.researchgate.net/publication/2543650 56_The_Bleaching_Syndrome_Among_People_of_C olö. DŌ। 10.1300/1 137v13n03_02> Accessed 28/3/2017.

Italian Trade Commission. (2008). The cosmetic \& personal care sector in India. Market Research.
<http://docplayer.net/I 4948674-The-cosmeticpersonal-care-sector-in-india-market-research2008.html> Accessed 22/l/2018.

Mire, Amina (20।0). "Pigmentation and Empire" New Black Magazine,

$<$ http://www.thenewblackmagazine.com/view.aspx?i ndex $=2382>$ Accessed 23/l/20l 8 .

Pradityo, Sapto (20|4). "Putih Tak Selalu Lebih Cantik" <http://majalah.detik.com/cb/ba5b094b3d97265a65 21910|4ee | 620/20|4/20|404|4 MajalahDetik I2 4.pdf $>$ Accessed 230/5/2017.

Robinson, Petra Alaine (20 I I). Skin bleaching in Jamaica: A Colonial Legacy. Dissertasiion paper, Texas: A\&M University.

< http://oaktrust.library.tamu.edu/bitstream/handle/I 9 69. I/ETD-TAMU-20 I I-05-9220/ROBINSONDISSERTATION.pdf?sequence $=2>$ Accessed 04/07/2017.

Srivastav, Taruka (20।7). Skin whitening cream sales still boom in India despite rules against ads deriding darker skin.

$<$ https://www.thedrum.com/news/20 I7/09/I5/skinwhitening-cream-sales-still-boom-india-despite-rulesagainst-ads-deriding > Accesed 18/7/2017.

Suny Levin Institute (20/4). Is Beauty Globalized? $<$ http://www.globalization I 01 .org/is-beautyglobalized-2/> Accessed 20/5/2016. 